\title{
Cara Pandang Gereja terhadap Kemiskinan dan Pembangunan
}

\section{R.F. Bhanu Viktorahadi ${ }^{*}$, Mochamad Ziaul Haq ${ }^{2}$, Yeni Huriani ${ }^{3}$}

1 Universitas Katolik Parahyangan Bandung, Indonesia; viktorahadi@yahoo.it

2 Program Integritas Terbuka RSCJ, Indonesia; em_zya@yahoo.com

3 UIN Sunan Gunung Djati Bandung, Indonesia; yenihuriani@uinsgd.ac.id

\section{* Correspondence}

Received: 2021-07-30; Accepted: 2021-08-30; Published: 2021-08-31

\begin{abstract}
Abstrak: Kemiskinan merupakan realitas sosial dalam dinamika kehidupan manusia di dunia. Realitas sosial ini juga merupakan bagian dari perhatian Gereja. Melalui struktur dinamisnya yang meliputi Kitab Suci, Tradisi, dan Magisterium, Gereja memberikan perhatian, kepedulian, dan menyampaikan ajarannya tentang kemiskinan beserta cara-cara penanggulangannya. Kajian ini bersifat penelitian literature, dengan kontekstualisasi Indonesia. Dengan analisis tekstual, tulisan ini menunjukkan bahwa dalam merefleksikan berbagai macam realitas yang berkaitan dengan kemiskinan, terutama dengan menggunakan pisau bedah Theology of Liberation, Gereja sampai pada kesimpulan bahwa kemiskinan, khususnya kemiskinan struktural adalah buah dari dosa sosial. Dosa sosial adalah dosa individu yang dibangun sedemikian rupa dengan berbagai macam pengkondisian sehingga menjadi suatu struktur yang masif. Kajian ini merekomendasikan perlunya kebutuhan akan pertobatan pribadi dan komunal untuk menghancurkan struktur dosa ini sekaligus mengangkat orang dari kemiskinan struktural.
\end{abstract}

Kata Kunci: Dosa; kemiskinan; ketidakadilan; pertobatan; solidaritas.

Abstract: Poverty is a social reality in the dynamics of human life in the world. This social reality is also part of the Church's concern. The Church pays attention, cares, and conveys its teachings about poverty and ways to overcome it through its dynamic structure, which includes Scripture, Tradition, and the Magisterium. This study is literature research, with Indonesian contextualization. By textual analysis, this paper shows that in reflecting on various realities related to poverty, especially by using the scalpel of Theology of Liberation, the Church has concluded that poverty, especially structural poverty, is the fruit of social sin. Social sin is an individual sin built in such a way with various kinds of conditioning to become a massive structure. This study recommends the need for personal and communal repentance to destroy this structure of sin and, at the same time, lift people out of structural poverty.

Keywords: Injustice; poverty; repentance; sin; solidarity.

\section{Pendahuluan}

Kemiskinan bukanlah sesuatu yang terjadi dengan sendirinya (Wibisono, 2021). Kemiskinan adalah hasil dari tindakan atau bahkan rekayasa pihak-pihak tertentu yang memperoleh keuntungan darinya (M. T. Rahman, 2018). Oleh karena itu, kemiskinan adalah masalah serius. Gagasan ini tentu bertentangan dengan gagasan kaum konservatif. Kaum konservatif tidak memandang kemiskinan sebagai masalah yang serius. Oleh karena itu, mereka percaya bahwa kemiskinan akan terselesaikan dengan sendirinya (Suryawasita, 1987).

Kemiskinan ini adalah buah langsung dari ketidakadilan struktural. Kemiskinan struktural terjadi akibat rendahnya akses sebagian masyarakat terhadap sumber daya yang terjadi dalam suatu sistem sosial budaya dan sosial politik sehingga tidak mendukung pembebasan kemiskinan dan sebaliknya menyebabkan tumbuh suburnya kemiskinan. Dalam perkembangannya, kemiskinan struktural 
banyak mendapat sorotan karena dipandang sebagai penyebab bertumbuh dan berkembangnya tiga kemiskinan lainnya, yaitu kemiskinan absolut, kemiskinan relatif, dan kemiskinan kultural (Jamasy, 2004).

Situasi ini memanggil Gereja untuk menjadi terang di tengah-tengah penderitaan dan kemiskinan masyarakat yang terjadi sebagai akibat struktur masyarakat yang tidak sosial atau tidak adil (Lestari \& Parihala, 2020). Panggilan ini sekaligus menunjukkan bahwa Gereja tidak pernah bisa mengingkari dan mengelakkan dirinya dari urusan dan keterlibatan pada perkara-perkara sosial-politik, termasuk kemiskinan dan pembangunan (Michel, 2017).

Kemiskinan terjadi akibat munculnya ketidakadilan. Ketidakadilan erat hubungannya dengan ketergantungan (Magnis-Suseno, 2019). Orang atau kelompok orang menderita ketidakadilan tidak memperoleh yang menjadi haknya karena ia tergantung dari orang atau kelompok orang lain. Ketergantungan dari kekuasaan pihak lain menyebabkannya ia tidak dapat memperjuangkan keadilan. Hal senada diungkapkan Leonardo Boff. Menurut Boff, kemiskinan muncul akibat persoalan ketidakadilan yang besar, bersamaan dengan kegagalan di dalam solidaritas dan persekutuan. Kemiskinan bersemi dari ketamakan yang terkekang dari sebagai individu dan negara yang melakukan ketidakadilan (Boff, 2011).

Ketidakadilan dapat dikategorikan menjadi dua jenis, yaitu ketidakadilan individual dan ketidakadilan sosial (ketidakadilan struktural). Ketidakadilan struktural ini tidak mudah dihadapi Gereja, karena tidak secara langsung disebabkan sikap seorang individu yang tidak adil. Ketidakadilan sosial ini terjadi secara bersama-sama melalui tindakan politis, ekonomis, dan sosial budaya. Walaupun tidak mudah, dalam perjalanan sejarahnya, sekurang-kurangnya sejak awal abad XX, Gereja telah turut berprihatin, bahkan terlibat langsung dengan kenyataan kemiskinan masyarakat dunia. Keterlibatan Gereja itu tertuang dalam Alkitab dan sejumlah dokumen yang menjadi ajaran bagi umatnya. Istilah yang lumrah digunakan dalam Gereja dalam menyampaikan ajarannya secara resmi adalah struktur dinamis. Struktur dinamis itu terwujud dalam tiga tahapan, yaitu Alkitab, Tradisi, dan Magisterium (Dister, 2020). Secara singkat, berdasarkan penyusuran ketiga tahapan itu, tulisan ini menguraikan cara pandang Gereja terhadap kemiskinan dan pembangunan.

\section{Hasil Penelitian}

\section{Alkitab tentang Kemiskinan}

Menurut Alkitab baik Perjanjian Lama maupun Perjanjian Baru, Tuhan tidak netral. Tuhan selalu berpihak kepada orang miskin dan menderita. Menurut Gustavo Gutiérrez, dalam Alkitab kemiskinan pertama-tama adalah suatu skandal yang tidak sesuai dengan martabat manusia. Oleh karena itu, kemiskinan bertentangan dengan kehendak Tuhan (Gutierrez, 1984: 291-293). Kondisi ini bukanlah akibat nasib, melainkan terutama akibat perbuatan tidak adil yang dilakukan pihak lain. Oleh karena itu, Alkitab senantiasa menyerukan perjuangan keadilan sosial, terutama bagi kaum miskin dan tertindas.

Kisah tentang persoalan atau perjuangan keadilan sosial tersebar di dalam Alkitab. Perjanjian Lama maupun Perjanjian Baru memperlihatkan bahwa adanya tiga definisi kaum miskin. Pertama, kaum miskin tidak ditentukan sifat religius mereka, tetapi lebih disebabkan kemiskinan fisik. Kedua, kaum miskin dalam Alkitab juga merupakan kaum dialektis yang disebabkan oleh kelompokkelompok yang bertindak tidak adil dan menyingkirkan mereka. Ketiga, kaum miskin dalam Alkitab adalah kelompok dinamis. Mereka bukanlah korban-korban pasif dalam sejarah (Smith, 2009). Melalui dan bersama mereka, Tuhan membentuk sejarah-Nya (Kim-Cragg, 2019).

Secara khusus dalam Perjanjian Lama sebagian besar pewartaan para nabi adalah tentang perjuangan keadilan sosial. Perjuangan tersebut mencakup tiga periode kenabian, yaitu sebelum pembuangan, masa pembuangan, dan setelah pembuangan. Nabi-nabi sebelum pembuangan adalah Amos, Yesaya, Mikha, Hosea, Zefanya, dan Habakuk. Nabi-nabi Masa Pembuangan adalah Yeremia, Yehezkiel, dan Deutero-Yesaya. Nabi-nabi sesudah Pembuangan adalah Yesaya, Zakaria, dan Maleakhi (Harold, 2018). 
Alkitab Perjanjian Lama menampakkan situasi penindasan atas Israel oleh bangsa-bangsa lain. Selain itu, penindasan juga terjadi di antara kaum Israel sendiri. Di dalam masyarakat Israel penindasan itu menyasar orang miskin. Pelaku penindasan atau pelaku ketidakadilan adalah orangorang kaya dan orang-orang berkuasa. Penindasan yang dimaksud adalah suatu penyalahgunaan kekuasaan serta penggunaan kekerasan untuk memaksakan kehendak, atau dalam bahasa yang lebih umum, perbuatan kasar dari si kuat terhadap si lemah. Pada kitab nubuat Yesaya, tindakan semacam ini termasuk dalam golongan tindak tidak menghormati Tuhan dan kehendak-Nya. Oleh karena itu, orang-orang semacam itu akan mendapatkan ancaman hukuman (Yes.3:1-4), yaitu (Pareira, 2006: 100101):

Maka sesungguhnya Tuhan, TUHAN semesta alam, akan menjauhkan dari Yerusalem dan dari Yehuda setiap orang yang mereka andalkan, segala persediaan makanan dan minuman: pahlawan dan orang perang, hakim dan nabi, petenung dan tua-tua, perwira dan orang yang terpandang, penasihat dan ahli sihir, dan orang yang paham mantera. Aku akan mengangkat pemuda-pemuda menjadi pemimpin mereka, dan anak-anak akan memerintah atas mereka (Yes.3:1-4).

Para nabi itu secara kasar mencela segala bentuk penindasan dan ketidakadilan, kecurangankecurangan, monopoli tanah, dan penyuapan terhadap hakim-hakim. Akan tetapi, kebanyakan perjuangan para nabi itu gagal untuk memberi dampak yang sungguh-sungguh atas masyarakat zamannya. Perjuangan para nabi menegakkan keadilan gagal karena mereka dipandang penguasa sebagai pemberontak terhadap status quo politik, sosial, ekonomi, dan agama zamannya. Mereka tidak dianggap sebagai pejuang keadilan. Mereka justru dianggap musuh sekaligus pengacau bangsa. Baru setelah pembuangan ke Babel, nabi-nabi memperoleh pengakuan. Malapetaka pembuangan itu menunjukkan bahwa nabi-nabi benar. Sebaliknya, para penguasa yang memanifestasi dalam mereka yang duduk di istana raja, para pemimpin militer, kalangan atas, dan kalangan agama bertindak salah karena melawan keadilan. Oleh karena itu, bangsa yang terhina itu berbalik kepada nabi-nabi untuk mencari harapan serta tuntunan (Harold, 2018).

Banyak kutipan dalam Alkitab Perjanjian Baru, seperti Injil menurut Markus, Matius, dan terutama Lukas serta Kisah Para Rasul, tentang orang miskin dan menderita. Aloysius Pieris (Pieris, 2018) membuat kategori-kategori secara lebih terperinci terkait kaum miskin di dalam Injil. Pieris membuat kategori-kategori itu karena menurutnya, salah satu keprihatinan yang perlu mendapat perhatian serius di Gereja Asia adalah kemiskinan yang mencolok (the overwhelming poverty). Keterlibatan Pieris dalam situasi kontekstual masyarakat Asia membuatnya tidak memiliki pilihan lain kecuali menanggapi secara bersama-sama persoalan kemiskinan massa dan masyarakat pluri-religius yang dihadapi gereja-gereja di Asia (Rubianto, 1996).

Pieris membuat tiga kategori untuk kaum miskin, yaitu: Pertama, kaum miskin adalah mereka yang secara sosial dikucilkan akibat aneka macam alasan. Misalnya, penyakit lepra dan penyakit jiwa. Kedua, kaum miskin adalah mereka yang secara sosial bergantung pada orang lain. Misalnya, janda dan yatim piatu. Ketiga, kaum miskin adalah mereka yang secara kultural ditundukkan (kaum perempuan dan anak). Kaum miskin adalah mereka yang memiliki cacat fisik (bisu, tuli, buntung kaki, buta), mereka yang secara psikologis tersiksa (kerasukan setan atau berpenyakit ayan), serta mereka yang secara spiritual rendah hati (orang-orang sederhana yang takut akan Tuhan dan para pendosa yang bertobat). Tidak semua kaum miskin yang rendah hati itu tanpa dosa. Tuhan memihak kaum miskin bukan karena mereka suci, melainkan karena mereka miskin dan menderita (J. B. S. J. Banawiratma, 2002).

Dalam kaitan dengan orang miskin, penginjil Lukas dikenal sebagai 'penginjil kaum miskin' (Woodington, 2020). Dalam bahasa sosiologi, Injil menurut Lukas adalah 'Injil sosial' (Harold, 2018). Cinta kasih Tuhan terhadap orang kecil dan miskin adalah salah satu ciri inti dalam pewartaan Injil. Tuhan mencintai semua orang, terlebih mereka yang kecil, miskin dan lemah. Cinta kasih itu tidak lepas dari kenyataan bahwa orang kecil dan miskin itu senantiasa menjadi korban para penguasa dan orang kaya (Lk.1:51-54), yakni:

Ia memperlihatkan kuasa-Nya dengan perbuatan tangan-Nya dan mencerai-beraikan orangorang yang congkak hatinya; Ia menurunkan orang-orang yang berkuasa dari takhtanya dan 
meninggikan orang-orang yang rendah; Ia melimpahkan segala yang baik kepada orang yang lapar, dan menyuruh orang yang kaya pergi dengan tangan hampa; Ia menolong Israel, hambaNya, karena Ia mengingat rahmat-Nya (Lk.1:51-54).

Secara khusus pewartaan Injil dalam Lukas memang menyasar orang miskin, melarat, tahanan, dan sakit itu. Khotbah di Bukit (Lk.6:20-26) dan perumpamaan tentang Lazarus (Lk.16:19-23) menjadi contoh jelas bahwa Injil memihak orang melarat dan tidak enggan menyebut celaka bagi orang kaya, sebagaimana dikatakan:

Berbahagialah, hai kamu yang miskin, karena kamulah yang empunya Kerajaan Allah. Berbahagialah, hai kamu yang sekarang ini lapar, karena kamu akan dipuaskan. Berbahagialah, hai kamu yang sekarang ini menangis, karena kamu akan tertawa. Berbahagialah kamu, jika karena Anak Manusia orang membenci kamu, dan jika mereka mengucilkan kamu, dan mencela kamu serta menolak namamu sebagai sesuatu yang jahat. Bersukacitalah pada waktu itu dan bergembiralah, sebab sesungguhnya, upahmu besar di sorga; karena secara demikian juga nenek moyang mereka telah memperlakukan para nabi. Tetapi celakalah kamu, hai kamu yang kaya, karena dalam kekayaanmu kamu telah memperoleh penghiburanmu. Celakalah kamu, yang sekarang ini kenyang, karena kamu akan lapar. Celakalah kamu, yang sekarang ini tertawa, karena kamu akan berduka cita dan menangis. Celakalah kamu, jika semua orang memuji kamu; karena secara demikian juga nenek moyang mereka telah memperlakukan nabi-nabi palsu (Lk.6:20-26).

Kemiskinan adalah suatu kondisi yang ditolak Alkitab. Dalam tafsirnya atas teks-teks Alkitabiah Gutiérrez menyatakan bahwa ada tiga alasan prinsip di balik penolakan Alkitab atas kemiskinan (Gutiérrez, 1988). Pertama, kemiskinan berlawanan dengan makna tindakan pembebasan Tuhan melalui Musa atas umat Israel dari perbudakan, penghisapan, dan alienasi di Mesir (Kel.16:6-8):

Sesudah itu berkatalah Musa dan Harun kepada seluruh orang Israel: 'Petang ini kamu akan mengetahui bahwa TUHANlah yang telah membawa kamu keluar dari tanah Mesir. Dan besok pagi kamu melihat kemuliaan TUHAN, karena Ia telah mendengar sungut-sungutmu kepadaNya. Sebab, apalah kami ini maka kamu bersungut-sungut kepada kami?' Lagi kata Musa: 'Jika memang TUHAN yang memberi kamu makan daging pada waktu petang dan makan roti sampai kenyang pada waktu pagi, karena TUHAN telah mendengar sungut-sungutmu yang kamu sungut-sungutkan kepada-Nya - apalah kami ini? Bukan kepada kami sungut-sungutmu itu, tetapi kepada TUHAN).

Kedua, kemiskinan bertentangan dengan mandat kitab Kejadian yang menjamin martabat manusia sebagai citra Tuhan (Kej.1:26 - "Berfirmanlah Tuhan: 'Baiklah kita menjadikan manusia menurut gambar dan rupa Kita, supaya mereka berkuasa atas ikan-ikan di laut dan burung-burung di udara dan atas ternak dan atas seluruh bumi dan atas segala binatang melata yang merayap di bumi"). Ketiga, kemiskinan tidak sesuai dengan hakikat manusia sebagai pribadi yang beriman kepada Tuhan dan yang harus mewujudkan iman tersebut dalam tindakan keadilan. Dengan demikian, Alkitab memandang kemiskinan sebagai skandal, yaitu situasi dosa yang menghalangi relasi sejati manusia dengan Tuhan dan sesamanya. Padahal, sebagai citra dan mitra penciptaan Tuhan, manusia harus senantiasa menjalin relasi dengan Tuhan dan sesamanya dalam tindakan yang berkeadilan sosial (Davies, 1998).

\section{Tradisi tentang Kemiskinan}

Tradisi Gereja seluas dan sepanjang dinamika zaman. Oleh karena kemiskinan menjadi bagian dari dinamika zaman itu, Tradisi pun memperhatikan dan berusaha memahaminya berdasarkan keprihatinan yang muncul. Dari sekian banyak Tradisi yang ada, dua di antaranya sangat berkepentingan dengan kemiskinan, yaitu dokumen-dokumen Konsili Vatikan II dan Ajaran Sosial Gereja (ASG). 


\section{Ajaran Konsili Vatikan II tentang Kemiskinan}

Paus Yohanes XXIII menyinggung tentang Gereja Orang Miskin dalam khotbah Pembukaan Konsili Vatikan II pada 12 Oktober 1962, meskipun kemudian tema kemiskinan atau masalah orang miskin tidak menjadi tema sentral konsili. Sudut pandang Kristologis dari Gereja Orang Miskin dan semangat kemiskinan dikemukakan di dalam dokumen Konsili Vatikan II, yaitu Konstitusi Dogmatis tentang Gereja 'Lumen Gentium' (LG) artikel 8, tentang Gereja miskin dan LG artikel 42, tentang semangat kemiskinan, yaitu:

Seperti Kristus melaksanakan karya penebusan dalam kemiskinan dan penganiayaan, begitu pula Gereja dipanggil untuk menempuh jalan yang sama, supaya menyalurkan buah-buah keselamatan kepada manusia. Kristus Yesus, 'walaupun dalam rupa Allah, ... telah mengosongkan diri-Nya dan mengambil rupa seorang hamba' (Flp.2:6-7). Bahkan dalam mereka yang miskin dan menderita Gereja mengenali citra Pendirinya yang miskin dan menderita, berusaha meringankan kemelaratan mereka, dan bermaksud melayani Kristus dalam diri mereka. Dalam hal ini, gereja itu suci dan sekaligus harus selalu dibersihkan, serta terus-menerus menjalankan pertobatan dan pembaharuan (LG.8).

Maka semua orang beriman kristiani diajak dan memang wajib mengejar kesucian dan kesempurnaan hidup mereka. Oleh karena itu, hendaklah semua memperhatikan, agar mereka mengarahkan keinginan-keinginan hati dengan tepat, supaya mereka dalam mengejar cinta kasih yang sempurna jangan dirintangi karena menggunakan hal-hal duniawi dan melekat pada kekayaan melawan semangat kemiskinan menurut Injil. Itulah maksud nasihat Rasul: Orang yang menggunakan barang dunia ini jangan sampai berhenti di situ: sebab berlalulah dunia seperti yang kita kenal sekarang (lih. 1Kor.7:31).

Lumen Gentium artikel 8 ini dibuka dengan pembicaraan tentang eklesiologi, yaitu pembicaraan tentang hakikat Gereja yang sekaligus kelihatan dan tak kelihatan. Setelah itu dilanjutkan secara berturut-turut tiga gagasan yang menggambarkan kondisi nyata Gereja yang dihidupi manusia dengan segala keterbatasannya, yaitu miskin, berdosa, dan menderita. Dengan demikian menjadi jelas bahwa Gereja yang dihidupi manusia konkret adalah Gereja yang memiliki keterbatasan. Ada tiga ciri yang menggambarkan keterbatasan itu, yaitu 'Gereja Miskin', 'Gereja Berdoa', dan 'Gereja Mengembara'.

Terkait Gereja Miskin, Konsili mengajarkan bahwa Gereja itu harus serupa dengan Kristus. Oleh karena Kristus itu miskin, Gereja juga harus miskin: "Seperti Kristus melaksanakan karya keselamatan dalam kemiskinan dan penganiayaan, begitu pun Gereja". Oleh karena itu, Gereja sendiri harus hidup miskin seperti Kristus. Gereja harus mengikuti kepalanya dalam perhatian dan cinta kasih-Nya terhadap orang miskin. Kemiskinan Kristus adalah tanda cinta kasih-Nya terhadap manusia. Sikap ini harus merupakan sikap Gereja pula. Kemiskinan Gereja pertama-tama adalah sikap dan rasa solidernya dengan orang miskin. Tanda bahwa Gereja adalah Gereja Kristus adalah saat pewartaan Gereja itu berpusat pada orang miskin dan kecil. Kemiskinan Gereja berarti Gereja bersama dengan Kristus menyatukan diri dengan orang miskin yang oleh Kristus disebut 'saudara-Ku' (Jacobs \& Dr, 1970).

Selanjutnya dokumen lain dari Konsili Vatikan II, yaitu Konstitusi Pastoral tentang Gereja di Dunia Dewasa ini 'Gaudium et Spes' (GS) artikel 1 juga menyampaikan ajakan kepada murid-murid Kristus supaya ikut serta dalam suka dan duka masyarakat, terutama yang miskin dan terlantar. Konstitusi Pastoral tentang 'Gereja di Dunia Dewasa ini' terdiri dari dua bagian yang merupakan suatu kesatuan. Konstitusi disebut 'pastoral' karena bermaksud menguraikan hubungan Gereja dengan dunia dan umat manusia zaman sekarang berdasarkan azas-azas ajaran. Oleh karena itu, bagian pertama tidak terlepas dari maksud pastoral, seperti bagian kedua pun tidak terlepas dari maksud mengajar.

Dalam bagian pertama, Gereja memaparkan ajarannya tentang manusia, tentang dunia yang didiaminya, dan tentang hubungannya dengan keduanya. Dalam bagian kedua ditelaah secara lebih cermat pelbagai segi kehidupan serta masyarakat manusia zaman sekarang. Khususnya, disoroti soalsoal dan masalah-masalah yang dewasa ini nampak lebih mendesak. Oleh karena itu, dalam bagian 
kedua ini bahan ulasan, berpedoman pada kaidah-kaidah ajaran, bukan hanya mencantumkan unsurunsur yang serba tetap, melainkan juga menyajikan hal-hal yang silih berganti. Dianjurkan supaya Konstitusi ini ditafsirkan menurut kaidah-kaidah umum penafsiran teologis. Secara khusus, dalam bagian kedua diminta diperhitungkan keadaan-keadaan yang dapat berubah yang pada hakikatnya tidak terpisahkan dari pokok-pokok yang diuraikan (Wilde, 2018).

Kegembiraan dan harapan, duka dan kecemasan orang-orang zaman sekarang, terutama kaum miskin dan siapa saja yang menderita, merupakan kegembiraan dan harapan, duka dan kecemasan para murid Kristus juga. Tiada sesuatu pun yang sungguh manusiawi, yang tak bergema di hati mereka. Sebab persekutuan mereka terdiri dari orang-orang, yang dipersatukan dalam Kristus, dibimbing oleh Roh Kudus dalam peziarahan mereka menuju Kerajaan Bapa, dan telah menerima warta keselamatan untuk disampaikan kepada semua orang. Maka persekutuan mereka itu mengalami dirinya sungguh erat berhubungan dengan umat manusia serta sejarahnya (GS 1).

Berbeda dengan yang diungkapkan Lumen Gentium, semangat dasar Konstitusi Pastoral tentang Gereja dalam Dunia Modern ini bukan tentang kepedulian terhadap orang miskin, melainkan mengenai pengakuan otonomi dunia. Dalam konteks itulah Gaudium et Spes menanggapi soal kemiskinan.

\section{Ajaran Sosial Gereja (ASG) tentang Orang Miskin}

Secara jelas, rinci, dan berkelanjutan Gereja merumuskan sikap serta ajarannya berhadapan kenyataan sosial-kemasyarakatan yang terus-menerus berubah, termasuk di dalamnya masalah kemiskinan. Sikap dan ajarannya itu tertuang dalam himpunan Ajaran Sosial Gereja (ASG) Katolik. Ajaran Sosial Gereja merupakan suatu proses diskusi dan refleksi Gereja semesta berhadapan dengan situasi sosial kemasyarakatan konkret. Buah-buah diskusi dan refleksi itu dituangkan dalam dokumendokumen yang menjadi ajaran sosial resmi Gereja. Biasanya, dokumen-dokumen itu dipublikasikan dalam wujud ensiklik-ensiklik dan surat apostolik. Sebagian besar dari ensiklik dan surat apostolik yang tergabung dalam ASG itu berbicara tentang kemiskinan. Oleh karena Ajaran Sosial Gereja mempunyai keprihatinan tertentu yang muncul dalam konteks zamannya sebagai tanggapan Gereja atas persoalan itu, tentu ada perkembangan atau pergeseran ajaran sosial Gereja dari waktu ke waktu. Ajaran Sosial Gereja berguna bagi Gereja untuk mencari makna bagi tindakan yang dilakukan sehingga meskipun tindakan itu terbatas hanya seputar tempatnya berada, tetapi tetap mengena pada nilai kemanusiaan dan keadilan yang berwawasan semesta (Schultheis, 1988).

Rerum Novarum (1891) adalah ensiklik pertama tentang Ajaran Sosial Gereja. Di dalam ensiklik ini, untuk pertama kali secara resmi Gereja mendekati persoalan buruh secara struktural. Artinya, mendiskusikan persoalan buruh sebagai masalah keadilan sosial. Masalah buruh tidak lagi dipandang sebagai masalah individual si pemilik perusahaan berhubungan dengan buruhnya. Rerum Novarum terutama membela dengan sepenuh hati martabat para pekerja yang tidak dapat dicabut, yang terkait dengan pentingnya hak milik, prinsip kerja sama di antara kelas-kelas sosial, hak-hak kaum lemah dan kaum miskin, kewajiban-kewajiban para buruh dan majikan, serta hak untuk berserikat (Komisi Kepausan, 2009). Sejak itu disadari bahwa kemiskinan buruh diangkat ke ranah sosial, sehingga penanganannya tidak cukup dengan tindakan karitatif saja.

Cara pandang struktural ini kemudian dikemukakan lagi dalam Ensiklik Quadragesimo Anno (1931). Ajaran sosial terpenting dari ensiklik ini adalah bahwa untuk pertama kalinya Gereja Katolik menetapkan prinsip solidaritas dan prinsip subsidiaritas. Kedua prinsip ini berfungsi mengatur struktur masyarakat demi mengatasi permusuhan kelas. Tanpa solidaritas dan subsidiaritas, yang lemah selalu kalah. Berdasarkan prinsip subsidiaritas ini, semua lembaga dari satu tatanan yang lebih tinggi harus menerapkan perilaku menolong (subsidium). Dengan tindakan itu, lembaga tersebut mendukung, memajukan, dan mengembangkan lembaga-lembaga dari tatanan yang lebih rendah. Dengan cara demikian satuan-satuan sosial perantara dapat secara tepat melaksanakan fungsi-fungsi yang diembankan kepadanya tanpa dipaksa untuk mengalihkannya secara tidak adil kepada satuan- 
satuan sosial lain dari tatanan yang lebih tinggi, yang menyebabkan satuan-satuan sosial perantara tadi akan terpuruk karena diserap dan digantikan. Akibatnya, martabat serta tempat mereka yang hakiki diingkari (Pius XI, 1931: 203).

Sedangkan dalam Ensiklik Mater et Magistra (1961) untuk pertama kali dalam Ajaran Sosial Gereja dibicarakan masalah kemiskinan yang dialami negara-negara berkembang, yaitu negara-negara yang membutuhkan bantuan. Melalui ensiklik ini, Paus mendesak negara-negara maju dan kaya untuk mengembangkan solidaritas antar-bangsa. Solidaritas secara khusus bertugas menonjolkan hakikat sosial yang intrinsik dari pribadi manusia, kesetaraan semua orang dalam martabat dan hak-hak, serta jalan bersama individu-individu dan bangsa-bangsa menuju kesatuan yang semakin kokoh. Tidak pernah sebelumnya terdapat suatu kesadaran yang tersebar luas mengenai ikatan saling ketergantungan antara individu-individu dan bangsa-bangsa yang ditemukan dalam setiap tingkatan (Yohanes XXIII, 1961: 415-417).

Setahun kemudian Paus Yohanes XXIII mengeluarkan Ensiklik Pacem in Terris (1962) yang menghubungkan masalah kemiskinan dan ketidakadilan dengan perdamaian. Perdamaian hanya bisa dicapai jika tidak ada kemiskinan atau ketidakadilan. Jika menghendaki perdamaian, manusia harus menghapus kemiskinan dan ketidakadilan. Dalam dokumen ini Paus Yohanes XXIII berpendapat bahwa perdamaian dapat ditegakkan hanya jika tata tertib yang ditentukan Tuhan dipatuhi sepenuhpenuhnya. Dengan berpegang seluas-luasnya pada akal budi dan tradisi hukum kodrat, Paus Yohanes XXIII memperinci daftar hak-hak yang harus dipenuhi orang-perorangan, pejabat, pemerintah negara dan masyarakat dunia. Perdamaian perlu didasarkan atas suatu aturan yang 'ditegakkan di atas kebenaran, dibangun sesuai dengan keadilan, dihidupkan dan diintegrasikan cinta kasih dan dilaksanakan dalam praktik dalam kebebasan' (Schultheis, 1988).

Selanjutnya Paus Paulus VI mengeluarkan Populorum Progressio (1967), ensiklik mengenai Ajaran Sosial Gereja pertama yang sepenuhnya berbicara tentang perkembangan bangsa-bangsa serta mengenai hubungan antara negara kaya dan negara miskin. Sedangkan dalam Surat Apostolik Octogesima Adveniens (1971) Paus Paulus VI membuka kepincangan-kepincangan antara negara kaya dan negara miskin. Ia juga membicarakan diskriminasi rasial dan alienasi oleh konsumerisme. Terkait konsumerisme yang menjadi salah satu penyebab kemiskinan, Octogesima Adveniens menyatakan bahwa kecenderungan pada eksploitasi 'yang acak-acakan' terhadap sumber-sumber daya ciptaan merupakan hasil dari proses historis dan kultural yang panjang (Paulus VI, 1971: 417).

Pada tahun yang sama Paus Paulus VI mengeluarkan dokumen De Iustitia in Mundo. Sebagai hasil Pernyataan Sinode Para Uskup se-Dunia, dokumen ini berbicara tentang penegakan keadilan sebagai dimensi konstitutif pewartaan Injil. Pewartaan Injil tanpa usaha menegakkan keadilan bukanlah pewartaan Injil yang sungguh-sungguh. Para uskup menegaskan bahwa prinsip-prinsip injili mengamanatkan keadilan demi pembebasan segenap manusia sebagai ungkapan hakiki dari cinta kasih Kristiani. Gereja harus bersaksi demi keadilan lewat gaya hidupnya sendiri, aktivitas-aktivitas pendidikan, dan aksi internasionalnya (Schultheis, 1988). Pengertian Gereja tentang keadilan adalah kehendak yang tetap dan teguh untuk memberikan kepada Tuhan dan sesama apa yang menjadi hak mereka (Aquinas, 1993). Dalam nada yang sama Paus Paulus VI menulis Surat Apostolik Evangelii Nuntiandi (1975). Dalam Surat Apostolik itu Paus menyatakan bahwa pewartaan Injil baru menjadi suatu pewartaan Injil yang utuh jika memperhatikan timbal balik antara Injil dan kehidupan konkrit manusia. Pewartaan Injil tidak boleh mengabaikan masalah-masalah keadilan, pembebasan dan perdamaian di dalam dunia.

Selanjutnya Paus Yohanes Paulus II mengeluarkan Ensiklik Laborem Exercens (1981) mengenai martabat kerja manusia. Menurut dokumen ini, kerja adalah suatu hak fundamental dan suatu kebaikan bagi umat manusia. Kerja adalah suatu kebaikan yang bermanfaat dan sepantasnya bagi manusia karena kerja merupakan cara yang tepat baginya untuk memberi ungkapan bagi dan mempertinggi martabat manusiawinya (Paulus II, 1981: 598-600). Martabat manusia pekerja sangat dijunjung tinggi. Ia mendesak perubahan radikal yang membela orang-orang tak berdaya berhadapan dengan orang-orang atau kelompok-kelompok berkuasa. Kerangka ajaran ini kemudian dilanjutkan dalam Ensiklik Sollicitudo Rei Socialis (1987). 
Ensiklik ini sangat menekankan perlunya perubahan struktur-struktur dan mekanismemekanisme yang tidak adil, serta perlunya solidaritas global. Melalui dokumen ini Paus Yohanes Paulus II menekankan bahwa Gereja dipanggil untuk membela orang miskin. Gereja harus berdiri di pihak orang miskin. Sedangkan dalam Ensiklik Centesimus Annus (1991), Paus Yohanes Paulus II mengemukakan kembali prinsip perhatian khusus bagi orang miskin, dengan beberapa nada baru. Antara lain, penilaian yang agak positif tentang ekonomi sistem pasar, ekonomi persaingan bebas, dan ekonomi internasional yang liberal. Akan tetapi, Paus Yohanes Paulus II tetap menekankan bahwa negara tetap harus berperan untuk mengatur sistem ekonomi pasar sehingga tidak mengorbankan orang miskin dan kecil (Paulus II, 1991: 853).

\section{Magisterium tentang Kemiskinan}

Dasar Alkitabiah dan dasar-dasar Tradisi Gereja yang terwujud dalam dokumen-dokumen Konsili serta Ajaran Sosial Gereja menemukan wujud aktual dan relevansi dalam sejumlah Magisterium (kuasa mengajar Gereja). Magisterium itu secara konkret terwujud dalam teologi atau ajaran yang berhadapan langsung dengan arus zaman. Aktualisasi teologi ini ditekankan Dr. Anton Gerrit Honig Jr (Honig, 1987) dalam tulisannya Exchange 32/33, 1982 (Honig, 1982). Salah satu penekanannya adalah bahwa teologi tidak pernah boleh merupakan tujuan di dalam dirinya sendiri. Menjadi tugas teologi untuk melayani orang-orang percaya yang mau tidak mau harus hidup dalam suatu konteks Anton Gerrit Honig kultural tertentu. Oleh karena itu, suatu teologi yang tidak memiliki sangkut paut dengan konteks tidak akan bermanfaat bagi gereja dan masyarakat setempat (Lambino, 1981). Dalam konteks kemiskinan dan pembangunan, teologi memandang perlunya Gereja mewujudkan dirinya secara konkret dalam kehidupan di tengah masyarakat modern dalam tiga cara, yaitu Gereja karitatif, Gereja solider, dan Gereja profetis.

\section{Gereja Karitatif}

Bentuk yang paling tua tanggapan terhadap orang miskin dan menderita adalah tindakan cinta kasih (caritas) berupa memberi derma, pakaian dan makan, melayani orang sakit dan yatim-piatu. Singkatnya, memberikan barang dan jasa yang dibutuhkan yang berkekurangan guna mengurangi penderitaan mereka. Paus Fransiskus dalam Anjuran Apostolik Evangelii Gaudium (EG - 2013) mengungkapkan bahwa Gereja masa kini adalah gereja yang terluka, sakit, dan kotor karena telah pergi keluar ke jalan-jalan, daripada suatu Gereja yang sakit karena hidupnya terkurung dan tergantung pada keamanan dan kenyamanannya sendiri (EG.49) (Elwood, 1992).

Karya karitatif bisa dalam dua model, yaitu karya karitatif individual dan karya karitatif institusional. Karya karitatif individual adalah tindakan amal secara perorangan. Misalnya, yang umumnya dilakukan orang-orang kaya dan juga dilakukan orang-orang berkuasa. Sedangkan karya karitatif institusional itulah yang dilakukan lembaga-lembaga bantuan, baik itu milik Gereja maupun milik masyarakat. Karya amal itu sesuatu yang sangat nyata dan sesuatu yang positif. Namun, Gereja karitatif ini tidak tanpa masalah atau tidak tanpa kritik. Masalahnya, apakah Gereja selalu memiliki secara memadai barang-barang untuk didermakan kepada orang miskin dan menderita. Itulah kritik terhadap model pendekatan karitatif ini. Orang miskin dan kecil yang menderita itu langsung dipandang sebagai 'objek', meskipun itu objek kebaikan. Orang kecil dan miskin itu dijadikan sebagai objek kebaikan atau sebagai objek belas kasihan. Dengan demikian, Gereja sudah menempatkan mereka sebagai orang di luar, sebagai bukan orang dalam atau yang menjadi bagian dari komunitas. Di sini Gereja seolah tidak sanggup lagi menerima mereka sebagai 'subjek' atau sebagai saudara (Magnis-Suseno, 1993).

Penderma yang pada umumnya adalah orang kaya dan orang berkuasa, membanggakan diri karena telah berbuat baik bagi orang miskin. Oleh karena itu, ia dihormati oleh masyarakat. Pendekatan karya amal ini memang mudah tergelincir kepada kesombongan sosial. Penderma memberikan sumbangan sering didampingi media untuk diwartakan, supaya diketahui banyak orang bahwa mereka telah berbuat baik bagi sesama. Gereja tidak menghapus model pendekatan karya amal ini. Bagaimanapun tindakan karitatif ini adalah model pelayanan tertua dalam Gereja. Dalam kondisi 
tertentu, seperti bencana alam, Gereja masih membutuhkan 'dapur umum'. Oleh karena itu, Gereja tetap pertahankan karya karitatif itu. Gereja hanya perlu dengan hati-hati supaya tidak tergelincir pada kesombongan sosial, yang juga sudah dikritik Yesus.

\section{Gereja Solider}

Bentuk tanggapan Gereja yang kedua dalam sejarah pelayanan Gereja terhadap yang menderita miskin dan sakit adalah solidaritas. Menurut Jon Sobrino, solidaritas adalah sesuatu yang berakar dari kenyataan historis, terutama kemiskinan. Kemiskinan itu menuntut orang di sekitarnya untuk mengambil sikap berbela rasa dan mengambil tindakan efektif untuk mengangkat orang dari situasi miskin tersebut (Sobrino \& Pico, 1985). Mengikuti Yesus berarti mengikuti sikap Yesus dan terutama sikap Allah sendiri, yang bersolider dengan manusia yang menderita dan berdosa. Salah satu sikap Yesus yang mencolok adalah solidaritas-Nya terhadap semua orang, terutama mereka yang sakit dan menderita, dengan pendosa, dan dengan mereka yang lapar. Bahkan, Ia solider sampai mati di kayu salib.

Kekhasan solidaritas kristiani adalah bahwa kesetiakawanan itu terlihat dalam sikap saat berhadapan dengan orang kecil yang miskin dan lemah dan bukan dalam sikap terhadap orang kaya dan orang berkuasa. Mengapa setiakawan dengan orang kaya atau berkuasa bukan solidaritas yang diharapkan Yesus? Menurut Yesus, solidaritas yang sebenarnya kelihatan saat Gereja tidak dapat mengharapkan balasan dari kebaikan tu. Sedangkan kesetiakawanan Gereja dengan orang kaya atau berkuasa selalu terbuka kemungkinan adanya balasan.

Sikap ini sesuai dengan pesan Injil, yaitu bahwa Tuhan tidak netral. Tuhan selalu berpihak. Tuhan selalu berpihak kepada orang miskin dan bukan orang kaya atau orang berkuasa. Tuhan berpihak pada orang miskin, bukan karena mereka memiliki sifat-sifat yang istimewa. Tuhan berada di pihak kaum miskin sebab mereka adalah orang yang tak berdaya dan tak seorang pun yang membela mereka. Keberpihakan Gereja kepada orang miskin diambil tidak berdasarkan suatu gambaran ideal mengenai orang miskin, seakan-akan pada mereka akan ditemukan segala kebajikan yang tidak ditemukan pada orang kaya dan orang berkuasa. Akan tetapi, itu dilakukan karena Gereja konsekuen pada komitmen kita dengan Tuhan sendiri yang berpihak orang miskin. Setiap penderitaan terhadap martabat pribadi manusia menimbulkan jeritan menuntut balas dari Tuhan sebab pencederaan tersebut merupakan perlawanan terhadap Pencipta dan setiap manusia ciptaan-Nya (Paulus II, 1991: 461).

\section{Gereja Profetis}

Solidaritas itu harus dimiliki setiap pengikut Kristus. Akan tetapi, keprihatinan atau solidaritas itu bersifat mendua. Di satu pihak sikap solidaritas memang merupakan dasar segenap perjuangan demi keadilan yang berorientasi pada manusia konkret. Di lain pihak sikap solidaritas itu tidak memadai karena bersifat sepihak dan tidak menghapus sebabnya, yaitu ketergantungan. Berprihatin dapat menjadi kedok untuk mengelak dari sikap dan tindakan yang harus dituntut dari Gereja, yaitu membebaskan mereka yang menderita miskin, mengakui hak mereka yang lemah dan melepaskan kekuasaan Gereja atas mereka.

Jika hanya sampai pada sikap 'karitatif' dan 'solider', berarti Gereja masih memandang bahwa kemiskinan dan penderitaan orang-orang kecil itu sebagai kenyataan alamiah, sebagai nasib, dan bukan sebagai akibat dari struktur sosial yang tidak adil. Karitas dan solidaritas tetap dipertahankan dan dijalankan. Akan tetapi, keduanya harus dilengkapi dengan sikap 'profetis'. Gereja harus berani membongkar ketidakadilan struktur-struktur masyarakat yang menyebabkan adanya kemiskinan atau boleh juga disebut pemiskinan.

Sikap profetis tersebut memiliki dua model, yaitu 'profetis kritis' dan 'profetis kreatif'. Profetis kritis, bermakna Gereja mengeritik atau membongkar sampai ke akarnya struktur sosial yang tidak adil yang menyebabkan kemiskinan atau pemiskinan itu. Sedangkan profetis kreatif bermakna Gereja melibatkan diri secara konkret mengambil tindakan mengatasi keadaan itu. Misalnya, membangun pertanian dan peternakan. Gereja membangun di sini sebenarnya juga menjadi suatu kritik kepada pemerintah, karena sesungguhnya pemerintahlah yang harus melakukan pembangunan itu. Dengan 
kata lain, harus dihindari bahaya sekadar mengkritik terus-menerus, tanpa usulan positif yang lebih baik.

Pendekatan profetis kreatif akan lebih meyakinkan daripada hanya melemparkan kritik (M Taufiq Rahman, 2014). Dalam model sikap profetis, ada tiga bentuk keterlibatan pada kaum miskin (Y. B. Banawiratma \& Muller, 1994): Pertama, terbatas dalam wujud kunjungan ke komunitas-komunitas orang miskin, pertemuan-pertemuan, pendampingan terbatas, dan dukungan terhadap komunitaskomunitas beserta gerakan-gerakan mereka. Kedua, kerja ilmiah. Wujudnya adalah menjalankan penelitian, menyampaikan penalaran profetis dan kritis-kreatif yang didorong keterlibatan praktis yang didasari keprihatinan terhadap komunitas tersebut. Ketiga, hidup di tengah dan bekerja bersama masyarakat miskin itu.

Menurut Seruan Apostolik Paus Yohanes Paulus II (1984), Reconciliatio et pænitentia", (Arokiasamy, 1991), dosa sosial (Nell-Breuning, 1987), memiliki tiga pengertian. Pertama, menunjuk pengaruh sosial atas dosa, sebagai akibat solidaritas manusiawi yang mengenai dan mempengaruhi orang lain. Kedua, dosa-dosa yang melawan sesama. Misalnya, dosa-dosa melawan keadilan yang dilakukan seorang individu melawan komunitas, maupun dilakukan komunitas melawan individu. Ketiga, melawan rencana Allah berkaitan dengan struktur-struktur sosial. Dalam arti terakhir ini dosa tertanam dalam struktur-struktur kehidupan masyarakat.

\section{Kesimpulan}

Kerinduan Gereja untuk mengikuti Yesus dan mencari serta menemukan Tuhan hanyalah otentik jika diwujudkan dalam keterlibatan kasih mendahulukan orang miskin dan menderita. Akan tetapi, perwujudan tanggung jawab sosial itu, baik dijalankan secara pribadi maupun secara institusional, selalu berhadapan dengan kenyataan, yang disebut 'dosa sosial' atau struktur-struktur dosa. Strukturstruktur dosa ini menjadi penyebab timbulnya kemiskinan.

Dosa sosial itu menciptakan lingkungan yang memungkinkan dosa personal dipermudah dan dianggap wajar. Di sini ada hubungan timbal balik antara dosa pribadi dan dosa sosial. Dosa pribadi memperkuat struktur dosa dan struktur dosa menyeret dosa pribadi. Struktur-struktur itu adalah kenyataan konkret, yang meskipun semula berakar pada dosa pribadi, pada gilirannya mempunyai kekuatan sendiri. Artinya, pada gilirannya kekuatan-kekuatan dosa yang terwujud dalam struktur sosial tersebut menjadi sulit dibasmi, juga kalau individu-individu menghendakinya.

Oleh karena dosa pribadi dan struktur dosa mempunyai hubungan timbal balik, pertobatan pribadi dan pertobatan sosial diperlukan supaya perubahan struktur demi kemajuan masyarakat dapat tercipta. Pertobatan personal mempunyai pengaruh sosial dan dapat menggerakkan pertobatan komunal. Pada gilirannya pertobatan personal dan pertobatan komunal diharapkan dapat mewujud dalam tindakan atau gerakan sosial yang bersifat struktural untuk mengubah struktur-struktur yang menindas. Dengan demikian, kemiskinan dan pembangunan menjadi ranah Gereja untuk mewujudkan tindak pertobatannya, yaitu dengan merintis, membangun, dan mengembangkan tindak berkeadilan bagi semua masyarakat di mana Gereja hidup dan berkarya.

\section{Referensi}

Aquinas, T. (1993). The Treatise on Law (Summa Theologiae, I-II; qq. 90-97). Indiana: University of Notre Dame Pess. Arokiasamy, S. (1991). Sinful Structures in the Theology of Sin, Conversion and Reconciliation. In S. Arokiasamy \& F. Podimattam (Eds.), Social Sin. Its Challenges to Christian Life. Bangalore: Claretian Publications.

Banawiratma, J. B. S. J. (2002). 10 agenda pastoral transformatif: menuju pemberdayaan kaum miskin dengan perspektif adil gender, HAM, dan lingkungan hidup. Yogyakarta: Penerbit Kanisius.

Banawiratma, Y. B., \& Muller, J. (1994). Berteologi Sosial Lintas Ilmu: Kemiskinan Sebagai Tantangan Hidup Beriman. Yogyakarta: Kanisius.

Boff, L. (2011). Passion of Christ, passion of the world. New York: Orbis Books.

Davies, E. W. (1998). R. Norman Whybray, Introduction to the Pentateuch. Journal of Semitic Studies, XLIII(1), 151152. https://doi.org/10.1093/jss/XLIII.1.151

Dister, N. S. (2020). Pengantar Teologi. Yogyakarta: Kanisius.

Elwood, D. J. (1992). Teologi Kristen Asia. Jakarta: BPK Gunung Mulia. 
Gutiérrez, G. (1988). A Theology of Liberation. Monthly Review, 36(3), 93. https://doi.org/10.14452/MR-036-03-198407_11

Harold, G. (2018). Evangelicals and social justice: Towards an alternative Evangelical community. Conspectus: The Journal of the South African Theological Seminary, 25(1), 21-37.

Honig, A. G. (1982). Exchange. Leiden: Interuniversitair Institute voor Misiologie en Oecumenica (IIMO) Leiden.

Honig, A. G. (1987). Ilmu Agama. Jakarta: BPK Gunung Mulia.

Jacobs, T., \& Dr, S. J. (1970). Konstitusi Dogmatis "Lumen Gentium" mengenai Gereja: Terjemahan, Introduksi, Komentar $I$ (Vol. 27). Yogyakarta: Kanisius.

Jamasy, O. (2004). Keadilan, pemberdayaan, dan penanggulangan kemiskinan. Jakarta: Belantika.

Kim-Cragg, H. (2019). Voices from the Margin: Interpreting the Bible in the Third World ed. by R. S. Sugirtharajah. The Catholic Biblical Quarterly, 81(1), 166-169. https://doi.org/10.1353/cbq.2019.0086

Komisi Kepausan untuk Keadilan. (2009). Perdamaian, Kompendium Ajaran Sosial Gereja. Maumere: Penerbit Ledalero.

Lambino, A. B. (1981). Zur theologischen Methode in der Kontextualisierung: Kritik an einigen asiatischen Ansätzen.(La méthode théologique adaptée au milieu. Critique de quelques essais en Asie). Zeitschrift Für Missionswissenschaft Und Religionswissenschaft Münster, 65(1), 1-13.

Lestari, D. T., \& Parihala, Y. (2020). Merawat Damai Antar Umat Beragama Melalui Memori Kolektif dan Identitas Kultural Masyarakat Maluku. Hanifiya: Jurnal Studi Agama-Agama. https://doi.org/10.15575/hanifiya.v3i1.8697

Magnis-Suseno, F. (1993). Beriman dalam Masyarakat. Butir-Butir Teologi Kontekstual. Yogyakarta: Penerbit Kanisius. Magnis-Suseno, F. (2019). Kekuasaan, Homoseksualitas, Kemunafikan? Majalah Rohani, 66(08), 10-14.

Michel, P. (2017). Contribution to a Socio-History of the Relations Between "Nation" and "Religion": The Case of Catholicism. In Religions, Nations, and Transnationalism in Multiple Modernities (pp. 19-36). New York: Palgrave Macmillan US. https://doi.org/10.1057/978-1-137-58011-5_2

Nell-Breuning, O. von. (1987). 'Soziale' Sünde oder institutionalisiertes Unrecht? Stimmen Der Zeit< Freiburg, Breisgau>, 205(3), 205-208.

Pareira, B. A. (2006). Kritik Sosial Politik Nabi Yesaya. In Malang: Penerbit Dioma. Malang: Penerbit Dioma.

Paulus II, P. Y. (1981). Ensiklik Laborem Exercens, 9, 18: AAS 73.

Paulus II, P. Y. (1991). Ensiklik Centesimus Annus, 48: AAS 83.

Paulus VI, P. (1971). Surat Apostolik Octogesima Adveniens, 21: AAS 63.

Pieris, A. (2018). Political Theologies in Asia. In The Wiley Blackwell Companion to Political Theology (pp. 250-263). Chichester, UK: John Wiley \& Sons, Ltd. https://doi.org/10.1002/9781119133759.ch18

Pius XI, P. (1931). Ensiklik Quadragesimo Anno: AAS 23.

Rahman, M. T. (2018). Pengantar filsafat sosial. Bandung: Lekkas.

Rahman, M Taufiq. (2014). Social Justice in Western and Islamic Thought: A Comparative Study of John Rawls's and Sayyid Qutb's Theories. Saarbruken: Scholars' Press.

Rubianto, V. (1996). Paradigma Asia: pertautan kemiskinan dan kereligiusan dalam teologi Aloysius Pieris. Yogyakarta: Kanisius.

Schultheis, J. (1988). Pokok-Pokok Ajaran Sosial Gereja. Yogyakarta: Kanisius.

Smith, S. (2009). Voices from the Margin: Interpreting the Bible in the Third World. Mission Studies, 26(1), $103-104$. https://doi.org/10.1163/157338309X450165

Sobrino, J., \& Pico, J. H. (1985). Theology of Christian Solidarity, trans. In Phillip Berryman (Maryknoll, NY: Orbis Books, 1985), p. II.

Suryawasita, A. (1987). Analisis Sosial. In J. B. Banawiratma (Ed.), Kemiskinan dan Pembebasan. Yogyakarta: Penerbit Kanisius.

Wibisono, M. Y. (2021). Agama dan Resolusi Konflik. Bandung: Lekkas dan FKP2B Press.

Wilde, M. J. (2018). Vatican II. Princeton: Princeton University Press.

Woodington, J. D. (2020). 4 The Gospel Of Luke. In The Dubious Disciples (pp. 98-136). Berlin: De Gruyter. https://doi.org/10.1515/9783110691788-005

Yohanes XXIII, P. (1961). Ensiklik Mater et Magistra: AAS 53.

(C) 2021 by the author. Submitted for possible open access publication under the terms and conditions of the Creative Commons Attribution (CC BY SA) license (https://creativecommons.org/licenses/by-sa/3.0/). 
Halaman ini sengaja dikosongkan 